\title{
THE DEVELOPMENT OF PILGRIMAGE TOURISM IN THE EXAMPLE OF JIZZAKH
}

\author{
Khakima Davlatova
}

Researcher Jizzakh State Pedagogical Institute Jizzakh, Uzbekistan

Shahobiddin Abdullayev

Researcher Jizzakh State Pedagogical Institute Jizzakh, Uzbekistan

\section{ABSTRACT}

This article discusses the development of pilgrimage tourism on the example of Jizzakh. The Jizzakh oasis has a long history, and the nature of the region fascinates at first sight. In particular, the Forish district of the region has a number of tourist attractions, where agritourism, ethno-tourism, water and pilgrimage tourism are developed. There is an ancient cave in the gorge. Stone images engraved on the eastern side of the monument at a height of two and a half meters indicate that people inhabited this area as early as the Bronze Age.

KEYWORDS:- Pilgrimage tourism, development, Jizzakh oasis, long history, nature of the region, Forish district, tourist attractions, agritourism, ethno-tourism, ancient cave, stone images, monument, bronze age.

\section{INTRODUCTION}

As a result of the intensive development of tourism and tourist services in recent years, new types of tourism have begun to form in the country - extreme, ecotourism, agritourism, archaeological, ethnographic tourism and others.

The most promising species are gaining momentum especially quickly - extreme and mountainous, which include hiking, cycling, motorcycle tourism, autotourism, paragliding and hang gliding.

Pilgrimage is an opportunity to turn to the Almighty through a saint, calm the mind and soul, understand the truth of holiness, walk the path of solitude and purification.
In Central Asia, this type of pilgrimage is called Pilgrimage, which means visiting holy places. Uzbekistan has always been the center of intersection of many cultures and civilizations, different religions were preached here and therefore unique monuments related to both Islamic, Buddhist and Christian religions have been preserved.

\section{The Main findings And RESUlTS}

On the territory of Uzbekistan, there are many holy places related to Islamic culture and its current Sufism, as well as other religions. The most valuable monuments are recognized as UNESCO World Heritage Sites. Among them is the city of Bukhara, called Bukhara-Sharif in the Islamic world, which means Blessed Bukhara. 
CURRENT RESEARCH JOURNAL OF PEDAGOGICS 2(7): 05-10, July 2021

DOI: https://doi.org/10.37547/pedagogics-crjp-02-07-02

ISSN 2767-3278

(C)2021 Master Journals

\section{Crossref do) 81 Google}

Accepted 08 ${ }^{\text {th }} J u l y, 2021$ \& Published $13^{\text {th }}$ July, 2021

The city of Samarkand, which has a huge number of priceless monuments. The city of Shakhrisabz is the birthplace of Amir Temur. Of course, these cities have an ancient and rich history, have undergone significant changes throughout their lives.

The department notes that the Jizzakh region is one of the promising regions of Uzbekistan, which includes all areas of tourism. In particular, the Forish district of the region has a number of tourist attractions, where agritourism, ethnotourism, water and pilgrimage tourism are developed.

In early September, in the Yukorichirchik district of the Tashkent region, the opening ceremony of the "Yik-Ota" shrine, which became a monument of cultural heritage, took place. The holy place created favorable conditions for Muslims and pilgrims. The complex includes a prayer room, a library, and spacious and comfortable courtyards.

There are many amazing places in our region worthy of the title of tourist and paradise. The Jizzakh region can also be referred to them. The Jizzakh oasis has a long history, and the nature of the region fascinates at first sight.

Stunning landscapes and unique climatic conditions, a variety of fauna and flora, give us the right to call the Jizzakh region one of the most beautiful corners of central Uzbekistan. The Nurata ridges surrounding its southern, partly western part of the oasis provide a temperate climate, as well as give the originality of the relief and natural beauty to the Aydar-Arnasay system to the lake in the north of the region.

We bring to your attention 10 reasons why you should visit this unique region of Uzbekistan.

The Zaamin State Reserve is located on a vast territory that includes the Bakhmal forestry, the Zaamin forestry, the Zaamin national natural park, the total area of which is 26840 hectares.
The reserve itself covers an area of 8,770 hectares.

It should be noted that the Zaamin State Reserve was created in 1928 on the mountain range of Turkestan in order to ensure the preservation of the unique juniper forests in this region and the fauna in their natural state. The protected areas mainly include mountain ranges. This reserve, located in the Zaamin and Bakhmal districts, has an altitude of 1670 to 4200 meters above sea level, the climate is sharply continental, the maximum temperature is 30 degrees. About 700 species of higher plants grow on the territory of the reserve. Of these, 13 species are listed in the Red Book of the Republic of Uzbekistan, 48 are endemic species.

The fauna of the reserve is diverse, 286 species of invertebrates, 29 species of mammals, 101 species of birds, 14 species of reptiles, 2 species of amphibians, 1 species of fish made this area their own. It should be noted that among them 13 species are included in the Red Book of the Republic of Uzbekistan.

Currently, the staff of the reserve is carrying out scientific work to study and preserve the flora and fauna of this territory. Also, together with professors, researchers and graduate students of the Faculty of Natural Sciences of the Jizzakh State Pedagogical Institute, many events, round tables on nature protection, ecology and environmental education in the scientific and spiritual-educational direction are jointly organized. We can also see this from their published scientific articles, brochures and media publications on the nature of the reserve and its conservation.

The Nurata Nature Reserve was created in the 70 s of the last century to preserve the population of a special subspecies of argali - Severtsev's ram, listed in the International Red Book (IUCN) and the Red Book of Uzbekistan. It also protects the genetic variety of the mountain walnut and 
CURRENT RESEARCH JOURNAL OF PEDAGOGICS 2(7): 05-10, July 2021

DOI: https://doi.org/10.37547/pedagogics-crjp-02-07-02

ISSN 2767-3278

(C)2021 Master Journals

\section{Crossref do) 8 Google}

Accepted 08thJuly, 2021 \& Published 13 ${ }^{\text {th }}$ July, 2021

the special fruit varieties grown here.

The complex is located in the village of Avlieota, Gallaral region and is divided into two parts. The upper part of the sanctuary is the outer territory of the complex, with beautiful and sacred springs, unique nature, inimitable landscapes. In the lower part is the tomb of Said ibn Abu Wakkos with ancient mosques and a mausoleum. The building of the mosque was built in the 19th century by the outstanding masters of their time - the master Kamil, the master Cairo, the master Zuhur and the master Mirzielar. The village of Avlieota beret appeared in the 7th century AD and is associated with the name of a close associate of the Prophet Muhammad - Said ibn Abu Wakkos, who was an Arab commander. who participated in the historical battle near the Mug Fortress.

Despite the fact that Said at that time met the seventeenth spring in his life, he was distinguished by the prudence and wisdom of a mature person, which is not typical of this age.

Said ibn Abu Wakkos, becoming an associate of Muhammad SAW, was one of the first to accept the Islamic faith at the age of 16 . There is also a holy spring and a small lake with the same name, which is inhabited by various plankton, including corals listed in the Red Book of Uzbekistan. The territory of the complex is 14.2 hectares.

At the foot of the Turkestan ridge, there are separate peaks that are its continuation. Here, on the western side of the peaks, there is a foothill called Morguzar; it is separated from the Nurata Mountains by the valley of the Sangzor River, where there are many gorges. The narrowest of the gorges is the $120-130 \mathrm{~m}$ wide gorge, popularly called the gate of Amir Temur.

According to legend, while walking along the terrain of the ruler of the Timurid empire Jahangir - he was Timur's great-grandson, he showed his army a mountain pass from both sides, after which this gorge began to be called by the name of Amir Temur. There is an ancient cave in the gorge. Stone images engraved on the eastern side of the monument at a height of two and a half meters indicate that people inhabited this area as early as the Bronze Age.

It is known for certain that the iron gates of Amir Timur are the strategic location of a system of fortifications and fortresses located on the Great Silk Road. The area is mentioned in the work of Babur - "Baburname". This gorge was also known as the Jizzakh Pass.

There are ancient inscriptions made at different times, one in Persian, made by order of Mirzo Ulugbek, the second belongs to the ruler Abdulalakhan, it was made after the victory over Dashti Kipchak, the third inscription was written by Nicholas II at the end of the XIX century, today this inscription has been removed from the stone.

The tourist routes of these two regions are interconnected and have a common content. For example, the unique natural monuments of the Farish State Reserve are interconnected with the places of residence of primitive people, found in the Nurata mountains, with ancient rock paintings. Or, for example, a tourist traveling to the area of Lake Aydar-Arnasay will not even notice how he ended up on the territory of the Jizzakh region.

In the direction of pilgrim tourism, both regions have many sacred places of worship that complement and continue each other. Territorial proximity, common roads, periodic and geographical interdependence of tourist sites require the joint development of domestic tourism.

Considering these general directions, the regional tourism development departments of Navoi and Jizzakh regions decided to jointly effectively use these opportunities. To this end, a 
CURRENT RESEARCH JOURNAL OF PEDAGOGICS 2(7): 05-10, July 2021

DOI: https://doi.org/10.37547/pedagogics-crjp-02-07-02

ISSN 2767-3278

(C)2021 Master Journals

\section{Crossref do) 8 Google}

Accepted 08thJuly, 2021 \& Published $13^{\text {th }}$ July, 2021

memorandum of cooperation was signed between the Jizzakh and Navoi regions on the development of domestic tourism.

On the basis of the agreement, the Jizzakh and Navoi regional khokimiyats will implement a number of joint long-term plans and projects to strengthen bilateral ties in the field of tourism, develop domestic and pilgrim tourism, improve the tourist infrastructure, create amenities for cultural recreation of the population, and support entrepreneurs conducting activities in this direction.

\section{Conclusion}

To this end, the parties agreed to jointly work within the framework of the "Travel in Uzbekistan" program to organize excursions and trips for groups of young people, residents of districts and labor collectives to eco and agritourism, cultural heritage and pilgrimage tourism in both regions. During the negotiations, special attention was paid to promoting the tourism opportunities of the regions in the media, on Internet sites and in social networks.

\section{REFERENCES}

1. Jurakhonovich, K. S. (2020). Pilgrimage Tourism in Uzbekistan; Problems and Solutions. Electronic Research Journal of Social Sciences and Humanities, 2, 262265.

2. Lapasovich, M. O., Nematovich, N. O., Yakubovich, Z. B., Rustamovich, U. M., \& Tolipov, F. (2020). HISTORICAL AND ETHNOGRAPHIC CHARACTERISTICS AND SOCIO-SPIRITUAL FACTORS OF VISITING TOURISM IN UZBEKISTAN. Journal of Critical Reviews, 7(6), 47-50.

3. Usmanov, M. (2020). HISTORICAL AND ETHNOGRAPHIC CHARACTERISTICS AND SOCIO-SPIRITUAL FACTORS OF VISITING
TOURISM IN UZBEKISTAN. Архив Научных Публикаций JSPI, 1-4.

4. Shakhzoda, S. (2021). The Pilgrimage Tourism Importance In The SocioEconomic Relations Development. Turkish Journal of Computer and Mathematics Education (TURCOMAT), 12(10), 50515055.

5. Tursunalievich, A. Z., Bulturbayevich, M. B., Ismatullayevich, S. I., Urayimovich, B. O., \& Yokubovna, Y. H. (2021). Use of Gravitation Models in the Development of Tourism and Recreation. Annals of the Romanian Society for Cell Biology, 3124-3143.

6. Saidmamatov, O., Matyakubov, U., Rudenko, I., Filimonau, V., Day, J., \& Luthe, T. (2020). Employing ecotourism opportunities for sustainability in the Aral Sea Region: Prospects and challenges. Sustainability, 12(21), 9249.

7. Egamberdiyeva, G. A. (2019). NEW DIRECTIONS IN THE DEVELOPMENT OF TOURISM IN THE REPUBLIC OF UZBEKISTAN. Theoretical \& Applied Science, (6), 211-220.

8. Tairova, M. M. Temirova DA-Bukhara State University, Undergraduate student WAYS TO IMPROVE CLUSTER APPROACH IN TOURISM.

9. Mirzaliyeva, S. (2021, April). COMBINATION OF NATIONAL AND FOREIGN EXPERIENCE IN THE DEVELOPMENT OF ECOTOURISM IN UZBEKISTAN.

10. Ugli, A. K. A. (2019). Mountain and Mountain Tourism in Uzbekistan: Potential and Development Factors. International Journal of Academic and Applied Research (IJAAR), 3(4).

11. Ibadullaev, E. (2021). OPPORTUNITIES 
CURRENT RESEARCH JOURNAL OF PEDAGOGICS 2(7): 05-10, July 2021

DOI: https://doi.org/10.37547/pedagogics-crjp-02-07-02

ISSN 2767-3278

(C)2021 Master Journals

Crossref doi 8 Google

Accepted 08thuly, 2021 \& Published $13^{\text {th }}$ July, 2021

AND PROSPECTS FOR THE

DEVELOPMENT OF TOURIST AND

RECREATIONAL SERVICES IN THE

REPUBLIC OF KARAKALPAKSTAN. Central

Asian Problems of Modern Science and Education, 2021(1), 22-36.

12. Patakhkamalovna, G. G. (2021). THE IMPORTANCE OF MODERN FORMS OF TERRITORIAL ORGANIZATION IN THE DEVELOPMENT OF TOURISM. Thematics Journal of Geography, 6(1).

13. Fatilloyevna, R. G., \& Bahriddinovna, U. D. (2021). THE ECONOMIC IMPORTANCE OF NATIONAL CRAFTS IN THE DEVELOPMENT OF TOURISM. Academy, (1 (64)), 52-54.

14. Melisovna, A. S. (2021). DEVELOPMENT OF ECOLOGICAL TOURISM IN UZBEKISTAN. EPRA International Journal of Multidisciplinary Research, 7(6), 270-273.

15. Gulyamovich, D. I. (2021). Problems of Organization of Tourist Zones in Free Economic Zones of Bukhara. CENTRAL ASIAN JOURNAL OF INNOVATIONS ON TOURISM MANAGEMENT AND FINANCE, 2(6), 28-39.

16. Xabibova, S. I., \& Usmanov, F. S. (2020). Level of Tourism Development in Uzbekistan at the Recent Stage. Indonesian Journal of Law and Economics Review, 8, 10-21070.

17. Islamovna, U. Z. (2021). Prospects for the development of the tourist and recreation complex as an effective lever for the restoration of the tourist industry in Uzbekistan after the pandemic. Academic Journal of Digital Economics and Stability, 6, 119-132.

18. Komilova, N. K. (2021). TOURIST DESTINATION AS AN OBJECT OF RESEARCH OF SOCIAL AND ECONOMIC
GEOGRAPHY. Psychology and Education Journal, 58(1), 2058-2067.

19. Doniyorov, A. K., \& Karimov, N. R. (2020). An Incomparable Book of a Great Scholar. Bulletin Social-Economic and Humanitarian Research, (6), 63-71.

20. Doniyorov, A., Kariev, A., Aminov, H., \& Karimov, N. (2021). The Level of Study of the Religious Image of Mavarounnahr in the IX-XII Centuries. Journal of Contemporary Issues in Business and Government, 27(1), 413-423.

21. ogli Odilov, B. A., \& Karimov, N. R. (2020). Analysis of Targeted Research in 20-30 Years of the XX Century. PalArch's Journal of Archaeology of Egypt/Egyptology, 17(6), 8887-8893.

22. Karimov, N. R. (2020). A True Successor of Great Central Asian Scholars. Journal «Bulletin Social-Economic and Humanitarian Research,(7), 62-69.

23. Karimov, N. R. (2017). Researches on the scientific heritage of hakim tirmizi in egypt. In Фундаментальные и прикладные научные исследования: актуальные вопросы, достижения и инновации (рр. 177-180).

24. Juraev, Z. M., \& Masalieva, O. M. (2020). Eleven Ahmad Pilgrimage And Seal And Flag Of Victory. The American Journal of Social Science and Education Innovations, 2(12), 43-50.

25. DAVLATOVA, K., \& NEMATOV, O. (2021). Tajiks of jizzakh oasis: traditional way of life, customs and traditions and rituals. Journal of Contemporary Issues in Business and Government, 27(3), 13241329.

26. МАСАЛИЕВА, О. М. (2021). ТАЗКИРАЛАРТАРИХИЙ МУХИМ МАНБА 
CURRENT RESEARCH JOURNAL OF PEDAGOGICS 2(7): 05-10, July 2021

DOI: https://doi.org/10.37547/pedagogics-crjp-02-07-02

ISSN 2767-3278

(C)2021 Master Journals

Crossref dof 81 Google

Accepted 08thJuly, 2021 \& Published 13 ${ }^{\text {th }}$ July, 2021

СИФАТИДА. In Uzbek Conference

Publishing Hub (Vol. 1, No. 01, pp. 123-

130).

27. Masalievna, M. O. (2017). LOCAL HISTORIOGRAPHY OF BUKHARA EMIRATE AT THE END OF NINETEENTH AND EARLY

TWENTIETH CENTURIES. Himalayan and Central Asian Studies, 21(4), 39. 